\title{
Comparison of Intraperitoneal Amino Acid and Oral Amino Acid Supplements in Peritoneal Dialysis Patients
}

Metin Sarikaya*, Feyza Bora, Ayca İnci, Funda Sari, Semih Gul, and Refık Olmaz

Education and Resezrch hospital, Antalya, Turkey

\begin{abstract}
Purpose: Among patients end-stage renal disease who receive peritoneal dialysis, malnutrition is an strong predictor of increased morbidity and mortality rates. In cases with malnutrition, hypoalbuminemia occurs mainly due to the leakage of albumin through peritoneal membrane. Therefore, the current study aimed to investigate and compare the effects of intraperitoneal or oral amino acid supplements in preventing hypoalbuminemia. 1.21 .2 Method: Our study included 36 patients on continuous ambulatory peritoneal dialysis (CAPD) in our center. In one group, one of the exchanges was replaced with a daily dose of $2000 \mathrm{ml}$ of peritoneal dialysis solution with $1.1 \%$ amino acids (AAs). The other group was given oral supplementation of keto/amino acids. The group receiving intraperitoneal (IP) AAs was composed of 16 patients, while oral keto/amino acid group included 20 patients. The baseline levels of serum albumin, prealbumin, transferrin, CRP, CO2, cholesterol panels and weights (recorded during PET) were compared with the values measured after 6 months of treatment.
\end{abstract}

Results: The baseline albumin levels in the IP AA group were lower than the Oral AA group $(p=0.008)$. When we categorized the patients based on their peritoneal membrane permeability, we found no difference between the peritoneal membrane permeability values of the groups and their laboratory variables $(p>0.05)$. At the end of month 6 , the BUN levels significantly elevated in the group receiving IP AA solution, whereas their levels of phosphorus and HDL declined $(p<0.05)$. The group receiving oral AAs supplement had lower levels of albumin and HbA1C at the end of month $6(p<0.05)$.

Conclusion: Although treatment with AAs supplements administered either intraperitoneally or orally, can be considered a good nutritional support, it should be borne in mind that the important point is to increase the amount of dietary protein intake in individual patients.

Keywords: Amino acids; Hypoalbuminemia; Malnutrition; Peritoneal dialysis

\section{Background}

Among patients with ESRD (End-Stage Renal Disease) who receive peritoneal dialysis treatment, the prevalence of protein-energy malnutrition (PEM) is considerably high and it is regarded as a strong predictor of increased morbidity and mortality rates. Identified by the International Society for Renal Nutrition and Metabolism in 2008, the diagnostic criteria for of protein-energy wasting are classified into 4 categories of abnormalities: 1) abnormal serum biochemistry, 2) reduced body mass, 3) reduced muscle mass, and 4) unintentional low dietary intakes [1]. In the development of PEM, various factors might play a role, which includes acidosis, insulin resistance and uremic toxins, inflammation, inadequate dialysis, hypercatabolic critical illness, protein and amino acid loss, insufficient protein and calorie intake [2-6]. In routine monitoring of patients with end-stage renal disease, the most prevalent instrument is the measurement for biochemical value of serum albumin level, where both lower intakes of certain nutrients and systemic inflammation are commonly associated with protein-energy wasting among dialysis dependent renal failure patients, which may lead to hypoalbuminemia $[7,8]$. It has been argued that prealbumin, also known as serum transthyretin, is a more accurate indicator of nutritional status than albumin, mainly because it has a shorter half-life in patients suffering from chronic kidney disease [9].

According to the prescription by the National Kidney FoundationKidney Disease Outcomes Quality Initiative (NKF KDOQI), dialysisdependent chronic kidney disease (CKD) patients are advised to consume a dietary protein of $1.2 \mathrm{~g}$ per kilogram body weight per day, which may not be completely viable in practice. Data from the most recent energy expenditure research show that, in accordance with the guidelines provided by the KDOQI, patients treated with peritoneal dialysis need a daily energy intake ranging from 30 to $35 \mathrm{kcal} / \mathrm{kg}$ based on their age [10]. However in reality, studies show that patient often fail to achieve such levels of protein and energy levels, with reported daily intakes of less than $1.0 \mathrm{~g} / \mathrm{kg}$ and $26 \mathrm{kcal} / \mathrm{kg}$ [11]. Amino acid losses into dialysate during continuous ambulatory peritoneal dialysis (CAPD) range from 2 to $4 \mathrm{~g}$, while 5-15 grams of proteins such as albumin, immunoglobulin, complement, transferrin, $\beta_{2}$-microglobulin, and $\alpha_{2}$ macroglobulin are lost [12-14] during a 24-hour collection period $[5,6]$.

The protein catabolic rate (PCR), a measure used to assess dietary protein intake in nutritionally stable patients receiving intermittent dialysis, is commonly considered a marker of protein catabolism. In cases with a normalized protein equivalent of nitrogen appearance (same as nPCR) of under $0.8 \mathrm{~g} / \mathrm{kg}$ or above, the mortality rate has been reported to increase, whereas the best survival rates have recently been shown to range from 1.0 to $1.4 \mathrm{~g} / \mathrm{kg}$ per day.

The purpose of this study was to investigate the changes in the levels of albumin, prealbumin, transferrin, $\mathrm{CRP}, \mathrm{CO}_{2}$, cholesterol panels and weight of our patients on CAPD after treatment with intraperitoneal (IP) amino acid solution and oral amino acid supplement for 6 months, comparing the efficacy of both nutritional supplements.

*Corresponding author: Metin Sarikaya, Department of Nephrology, Education and Resezrch hospital, Antalya, Turkey, Tel: +90 5057963534; E-mail: dr.metinsarikaya@gmail.com

Received November 14, 2014; Accepted January 23, 2015; Published January 29, 2015

Citation: Sarikaya M, Bora F, Inci A, Sari F, Gul S, et al (2015) Comparison of Intraperitoneal Amino Acid and Oral Amino Acid Supplements in Peritoneal Dialysis Patients. J Nephrol Ther 5: 192. doi:10.4172/2161-0959.1000192

Copyright: (c) 2015 Sarikaya M, et al. This is an open-access article distributed under the terms of the Creative Commons Attribution License, which permits unrestricted use, distribution, and reproduction in any medium, provided the original author and source are credited. 


\section{Method}

The current study included 36 patients receiving CAPD treatment in our institution. The inclusion criteria were as follows: age greater than 18, clinical stability, no history of peritonitis episode within 6 months, and no congestive heart failure or malignancy. Prior to initiation of the study protocols, the participants were given a peritoneal equilibration test (PET) using a 2.27\% glucose-based PD solution. After the dialysateto-plasma concentration $(\mathrm{D} / \mathrm{P})$ ratio for creatinine was calculated, the patients were divided into 4 groups (as low, medium-low, mediumhigh and high) based on their peritoneal membrane permeability rates. Due to possible difficulties in calculating the amount of protein intakes, we used normalized protein catabolic rates (nPCR) derived from the PET results for accurate measurement of protein intakes. The patients were divided into two groups as those nPCR's below $0.8 \mathrm{~g} / \mathrm{kg} / \mathrm{day}$. In one group, one of the previous exchanges was replaced with a daily dose of $2000 \mathrm{ml}$ of peritoneal dialysis solution with $1.1 \%$ amino acids (Nutrineal' by Baxter). During the study period (6 months), daily doses of 1 exchange were administered at noon to the peritoneal cavity. The solution with amino acids (AAs) remained in the peritoneal cavity of the patient for 6 hours. The other group was given oral keto/amino acid supplements (Table 1 ). The patients in this group were prescribed with oral keto/amino acids (Ketosteril $600 \mathrm{mg}$ by Fresenius), 5 tablets 3 times a day (a total of 15 tablets a day). The group receiving IP AAs consisted of 16 patients, while oral keto/amino acid group included 20 patients. The patients' levels of serum albumin, prealbumin, transferrin, $\mathrm{CRP}, \mathrm{CO}_{2}$, cholesterol panels and weights were measured at baseline (recorded during PET) and at the end of the study period (month 6).

Prior to the initiation of any study protocols, a written approval was obtained from the Ethics Committee of Antalya Education and Research Hospital.

\section{Biochemistry}

The levels of transferrin were determined by using commercially available assay kits (Abbott) with an autoanalyzer (Architect ${ }^{\circ}$ c16000, Abbott Diagnostics). The levels of hemoglobin was determined by using fully automated hematology analyzer (Sysmex 'xt-2000i, Roche Diagnostics) PTH level were measured using the Access Hybridtech two-site immunoenzymatic "sandwich" assay (Beckman Coulter, Fullerton, CA). Serum calcium, albumin, prealbumin, total Carbonsiokside, glucose levels and lipid panel were determined by using commercially available assay kits(Abbott) with an autoanalyzer (Architect ${ }^{\circ}$ c16000, Abbott Diagnostics).

A nephelometric method was used for measuring CRP levels (Delta Array $^{\oplus}$ Protein System, SEAC Diag- nostics).

\section{Statistical Analysis}

Descriptive statistics were used to summarize the data for categorical variables, this included frequencies and percentages, and for continuous variables, this included mean \pm standard deviation (SD). The Kolmogorov-Smirnov test was used to verify the normality of the distribution of continuous variables. Since none of the continues variables normally distributed comparisons between two groups were performed either with an Mann Whitney U test, Wilcoxon Sign Rank test or a Chi-Square test. Analyses were performed with PASW 18 (SPSS/IBM, Chicago, IL, USA) software. Differences were considered statistically significant when the probability value $(\mathrm{P})$ was $\backslash 0.05$.

\section{Results}

Table 2 shows the characteristics and baseline values of the participants, categorized into two groups as those receiving IP solution with AAs and oral keto/amino acid supplements. There was no statistically significant difference between the variables $(p>0.05)$.

Table 3 lists the variables with statistically significant difference between the baseline (month 0 ) and month 6 in patients receiving the AA support, regardless of their groups.

At the baseline, there were 5 patients with nPCR of below $0.8 \mathrm{~g} /$ $\mathrm{kg}$ per day in the IP AA group, while the oral AA group contained 11 people with such rates. The group treated with IP AAs had 4 patients with a Kt/V of less than 1.7, and the oral AA group had 5 patients. There was no statistical difference between these groups.

The baseline mean albumin level in the IP AAs group was $3.1 \pm$ $0.58 \mathrm{~g} / \mathrm{dl}$, while in oral AAs group, it was $3.5 \pm 0.47 \mathrm{~g} / \mathrm{dl}$, and there was significant difference between the groups $(p=0.008)$.

At the baseline, in the IP AAs group, there were 5 patients with albumin levels of below $3 \mathrm{~g} / \mathrm{dl}$, and 11 people had albumin levels over $3 \mathrm{mg} / \mathrm{dl}$. These two groups had differences in hemoglobin levels $(p=0.012)$. The mean hemoglobin level in the group with albumin less than $3 \mathrm{~g} / \mathrm{dl}$ was $9.6 \pm 0.53 \mathrm{mg} / \mathrm{dl}$, while the group with albumin levels over $3 \mathrm{~g} / \mathrm{dl}$ had mean hemoglobin level of $11.5 \pm 1.7 \mathrm{mg} / \mathrm{dl}$.

When we categorized the patients according to their peritoneal membrane permeability, we found no difference between the membrane permeability values and their laboratory variables $(p<0.05)$.

Table 4 shows the differences in the laboratory findings of the patients treated with IP solution with AAs.

Table 5 shows the differences in the laboratory values of the patients treated with oral keto/amino acid supplement.

At the end of the study period, we detected no difference in terms of the laboratory findings between the groups treated with either intraperitoneal AA solution or oral AA supplements $(p>0.05)$.

On the other hand, of the 16 patients receiving IP AAs, 7 had albumin levels below $3 \mathrm{mg} / \mathrm{dl}$, while in the oral AA group (20 patients), only 6 individuals had albumin levels below $3 \mathrm{mg} / \mathrm{dl}$.

At month 6, in the IP AA group, there were 5 patients with albumin

\begin{tabular}{|l|c|}
\hline $\begin{array}{l}\text { (RS)- -3-methyl-2-oxo-valerate } \\
\text { (DL-a-lsoleucine ketoanalog) the calcium salt }\end{array}$ & $67 \mathrm{mg}$ \\
\hline $\begin{array}{l}\text { (DL-İzolösin a-ketoanaloğu) kalsiyum tuzu } \\
\text { 4-methyl-2-oxo-valeric acid } \\
\text { (A-ketoanalog Leucine), calcium salt }\end{array}$ & $101 \mathrm{mg}$ \\
\hline $\begin{array}{l}\text { 2 - oxo-3-phenyl propionic acid } \\
\text { (A-ketoanalog Phenylalanine), calcium salt }\end{array}$ & $68 \mathrm{mg}$ \\
\hline $\begin{array}{l}\text { 3 - methyl-2-oxo-butyric acid } \\
\text { (A-ketoanalog Valine), calcium salt }\end{array}$ & $86 \mathrm{mg}$ \\
\hline $\begin{array}{l}\text { RS-2-hydroxy-4-(methylthio)-butyric acid } \\
\text { (Alpha-hydroxy analog of methionine), calcium salt }\end{array}$ & $59 \mathrm{mg}$ \\
\hline $\begin{array}{l}\text { L-lysine acetate } \\
\text { (75 mg L-lysine-eq) }\end{array}$ & $105 \mathrm{mg}$ \\
\hline L-threonine & $53 \mathrm{mg}$ \\
\hline L-tryptophan & $23 \mathrm{mg}$ \\
\hline L-histidine & $38 \mathrm{mg}$ \\
\hline L-tyrosine & $30 \mathrm{mg}$ \\
\hline Total nitrogen content for each tablet & $36 \mathrm{mg}$ \\
\hline The amount of calcium for each tablet & $1,25 \mathrm{mmoL}=50 \mathrm{mg}$ \\
\hline
\end{tabular}

Table 1: Composition of the Oral Keto Amino Acids 


\begin{tabular}{|c|c|c|}
\hline Groups & IP AA & Oral AA \\
\hline Gender (male/female) & $8 / 8$ & $12 / 8$ \\
\hline Age (years) & $58 \pm 11.4$ & $52.5 \pm 12$ \\
\hline Dialysis duration (months) & $48 \pm 46.9$ & $41 \pm 19.5$ \\
\hline Kt/ $/ 2.3 \pm 0.6$ & $2.1 \pm 0.5$ \\
\hline nPCR (g/kg/d) & $0.91 \pm 0.24$ & $0.76 \pm 0.16$ \\
\hline \multicolumn{2}{|c|}{ Etiology } \\
\hline DM & 4 & 4 \\
\hline HT & 7 & 6 \\
\hline GN & 0 & 1 \\
\hline Unknown cause & 0 & 1 \\
\hline Residual Renal Function (Yes/No) & 5 & 8 \\
\hline \multicolumn{2}{|c|}{ PET permeability test } & $18 / 2$ \\
\hline Low-medium & 5 & 8 \\
\hline Low & 1 & 1 \\
\hline High & 3 & 2 \\
\hline High-medium & 7 & 9 \\
\hline
\end{tabular}

Table 2: Characteristics of Patients Receiving Amino Acid (AA) Replacement

\begin{tabular}{|c|c|c|c|}
\hline Variables & Month 0 & Month 6 & $\boldsymbol{P}$ value \\
\hline Albumin (g/dl) & $3.3 \pm 0.56$ & $3.1 \pm 0.71$ & 0.002 \\
\hline BUN (mg/dl) & $45.1 \pm 12.5$ & $51.5 \pm 18.2$ & 0.021 \\
\hline P (mg/dl) & $4.7 \pm 1.3$ & $4.05 \pm 1.09$ & 0.005 \\
\hline HDL (mg/dl) & $37.8 \pm 10.4$ & $34.8 \pm 10.4$ & 0.03 \\
\hline HbA1c (\%) & $5.4 \pm 1.35$ & $5.1 \pm 1.1$ & 0.044 \\
\hline
\end{tabular}

Table 3: Variables showing significant differences between month 0 and month 6

levels less than $3 \mathrm{mg} / \mathrm{dl}$, and 11 patients with albumin levels above 3 $\mathrm{mg} / \mathrm{dl}$. These two groups had significant differences in CRP values $(p=0.008)$. The mean CRP was $29.9 \pm 19.6(\mathrm{mg} / \mathrm{L})$ in the group with albumin levels below $3 \mathrm{mg} / \mathrm{dl}$, while the group with albumin levels over $3 \mathrm{mg} / \mathrm{dl}$ had a mean CRP of $3 \pm 10.4(\mathrm{mg} / \mathrm{L})$ (3.08 to 35.2$)$.

\section{Discussion}

The current study showed that neither intraperitoneal AAs solution nor oral keto/amino acid supplement had a positive contribution to the biochemical markers of nutrition such as albumin, prealbumin, and transferrin. With the diagnosis of PEM, a multifaceted approach should be adopted in the management of the disease, which incorporates dietary supplements, optimization of dialysis, as well as metabolic acidosis correction. In patients receiving peritoneal dialysis treatment, a nutrition expert should be always consulted for a better management. In comparison with hemodialysis (HD) patients, the individuals treated with peritoneal dialysis, who suffer difficulties maintaining oral intake, need to receive more dietitian support to regulate their protein and calorie intake. The specific mechanisms triggering appetite suppression in patients with kidney failure are not yet to be established. However, it has been proposed that the involvement of the proinflammatory cytokines, including tumor necrosis factor-alpha, IL-1 beta, and IL-6 as well as ghrelin, leptin, adiponectin, may be altering the function of key neurotransmitters and neuropeptides, inducing anorexia and wasting syndrome $[15,16]$. The lack of appetite in patients receiving PD treatment may be caused by several factors such as inadequate dialysis and feeling of fullness in the stomach due to intra-abdominal pressure increased by the presence of peritoneal dialysis fluid. Nearly one-third of the reported elevation in dietary protein need is caused by the constant protein and amino acid loss during peritoneal dialysis, which may be compensated by sufficient dietary intake, though loss of appetite or anorexia usually restricts adequate intake in most patients
[14]. Both protein degradation and decarboxylation of the branchedchain AAs are increased by metabolic acidosis through stimulation of the glucocorticoid-dependent ubiquitin-proteasome pathway $[3,17,18]$.

In PD patients, in order to compensate protein loss, albumin and fibrinogen production usually elevates, so do the synthesis of other liver-secreted proteins [19]. Some studies have argued that increased albumin synthesis to compensate transperitoneal losses of albumin is usually reduced by inflammation [20].

As influenced by volume status and inflammation, association of serum albumin levels with nutritional status brings certain drawbacks. Protein supply can stimulate albumin synthesis, mainly in protein depletion states [21-23]. Besides, like albumin, prealbumin is also suppressed in inflammation states [24]. In cases with deficiency of dietary protein intake (DPI), synthetic and catabolic rates of albumin tend to decline, which causes albumin levels to be preserved [25]. Even though serum albumin concentration is not considered an effective marker of nutritional status, it is still the most commonly used instrument in clinic settings [26-29]. In our study, the albumin levels remained unchanged in the IP AAs group, while the group receiving oral amino acid supplements had declined levels of albumin, which may be associated with loss of amino acids through the peritoneum or wasting in the process of catabolism. It can be suggested that the amount of absorbed amino acids in IP solution with AAs is relatively higher than oral amino acid supplements. The significantly higher CRP in the group with albumin levels below $3 \mathrm{mg} / \mathrm{dl}$ after treatment with IP AAs for 6 months implies that inflammation may also be contributing to the decrease in albumin levels.

The findings of the CANUSA (Canada and USA) study indicated that better nutritional status and increased doses of total weekly urea clearance are associated with higher patient survival rates [30]. It is considered that delivery of higher small solute clearance by dialysis to improve dietary protein intake (DPI). This assumption originates from the high correlation found between $\mathrm{Kt} / \mathrm{V}$ (dialysis adequacy) and nPCR, in which PCR is used as indirect index to predict dietary protein intake. However, specific concerns regarding the mathematical coupling between $\mathrm{nPCR}$ and $\mathrm{Kt} / \mathrm{V}$ have been highlighted [31]. In our study, as we were unable to calculate the protein intake precisely, consistent with the way previous researchers have employed [32,33], we used $\mathrm{Kt} / \mathrm{V}$ and $\mathrm{nPCR}$ to predict the relative protein intake of our patients, although an artificial mathematical correlation due to coupling was expected. In the beginning of our study, no difference was found between groups for $\mathrm{nPCR}$ and $\mathrm{Kt} / \mathrm{V}$, which ensured a roughly homogeneous study sample in terms of nutritional status.

It has been debated whether nutritional status of patients are affected by rapid transport status or protein loss. A cross-sectional study conducted with 147 patients receiving PD correlated a rapid transport status with protein loss, associating a higher composite nutritional index score and reduced levels of insulin-like growth factor-1 with decreased lean body mass, which was predicted by creatinine kinetics [34]. Findings of previous research imply that higher peritoneal permeability in CAPD patients can be considered an adverse factor for malnutrition $[34,35]$. In contrast to these earlier findings, the current study showed no significant effect of peritoneal membrane permeability on nutritional status, which may be related to relatively small sample size of our study.

The circulating and intracellular levels of essential amino acids (mostly leucine and valine) in patients on peritoneal dialysis are usually 
Citation: Sarikaya M, Bora F, İnci A, Sari F, Gul S, et al (2015) Comparison of Intraperitoneal Amino Acid and Oral Amino Acid Supplements in Peritoneal Dialysis Patients. J Nephrol Ther 5: 192. doi:10.4172/2161-0959.1000192

Page 4 of 7

\begin{tabular}{|c|c|c|c|}
\hline Variables & Month 0 & Month 6 & $P$ value \\
\hline BUN (mg/dl) & $45.1 \pm 12.3$ & $49.8 \pm 20.2$ & \\
\hline Albumin (g/dl) & $3.5 \pm 0.47$ & $3.2 \pm 0.79$ & 0.04 \\
\hline Prealbumin & $30.7 \pm 5.5$ & $29.9 \pm 3.79$ & \\
\hline Transferrin (mg/dl) & $195 \pm 50$ & $192 \pm 49.9$ & \\
\hline Calcium (mg/dl) & $9.2 \pm 0.85$ & $8.7 \pm 1.16$ & \\
\hline Phosphorus (mg/dl) & $4.7 \pm 1.3$ & $4.102 \pm 1.1$ & \\
\hline Parathormone (pg/ml) & $180 \pm 173(5-596)$ & $147173(7-626)$ & \\
\hline LDL (mg/dl) & $113.2 \pm 34.3$ & $111.1 \pm 33.9$ & \\
\hline HDL (mg/dl) & $38.9 \pm 11$ & $37.25 \pm 12.7$ & \\
\hline Total $\mathrm{CO}_{2}(\mathrm{mEq} / \mathrm{L})$ & $28.3 \pm 3.3$ & $28.5 \pm 2.58$ & \\
\hline Glucose (mg/dl) & $116.3 \pm 43.9$ & $124 \pm 47(84-291)$ & \\
\hline HbA1c (\%) & $5.5 \pm 1.5$ & $5.17 \pm 1.26$ & 0.044 \\
\hline CRP (mg/L) & $21.8 \pm 54.5(3.1-251)$ & $15.5 \pm 13.5(3.5-50.3)$ & \\
\hline $\mathrm{Hgb}(\mathrm{mg} / \mathrm{dl})$ & $11.7 \pm 1.7(8.3-15.5)$ & $10.9 \pm 1.9(7.7-15)$ & \\
\hline Weight (kg) & $71 \pm 13.2$ & $72.1 \pm 13.9$ & \\
\hline
\end{tabular}

Table 4: Differences in parameters of patients receiving IP AAs

\begin{tabular}{|c|c|c|c|}
\hline Variables & Month 0 & Month 6 & $P$ value \\
\hline BUN (mg/dl) & $45.1 \pm 12.3$ & $49.8 \pm 20.2$ & \\
\hline Albumin (g/dl) & $3.5 \pm 0.47$ & $3.2 \pm 0.79$ & 0.04 \\
\hline Prealbumin & $30.7 \pm 5.5$ & $29.9 \pm 3.79$ & \\
\hline Transferrin (mg/dl) & $195 \pm 50$ & $192 \pm 49.9$ & \\
\hline Calcium (mg/dl) & $9.2 \pm 0.85$ & $8.7 \pm 1.16$ & \\
\hline Phosphorus (mg/dl) & $4.7 \pm 1.3$ & $4.102 \pm 1.1$ & \\
\hline Parathormone $(\mathrm{pg} / \mathrm{ml})$ & $180 \pm 173(5-596)$ & $147173(7-626)$ & \\
\hline LDL (mg/dl) & $113.2 \pm 34.3$ & $111.1 \pm 33.9$ & \\
\hline HDL (mg/dl) & $38.9 \pm 11$ & $37.25 \pm 12.7$ & \\
\hline Total $\mathrm{CO}_{2}(\mathrm{mEq} / \mathrm{L})$ & $28.3 \pm 3.3$ & $28.5 \pm 2.58$ & \\
\hline Glucose (mg/dl) & $116.3 \pm 43.9$ & $124 \pm 47(84-291)$ & \\
\hline HbA1c (\%) & $5.5 \pm 1.5$ & $5.17 \pm 1.26$ & 0.044 \\
\hline CRP (mg/L) & $21.8 \pm 54.5(3.1-251)$ & $15.5 \pm 13.5(3.5-50.3)$ & \\
\hline $\mathrm{Hgb}(\mathrm{mg} / \mathrm{dl})$ & $11.7 \pm 1.7(8.3-15.5)$ & $10.9 \pm 1.9(7.7-15)$ & \\
\hline Weight (kg) & $71 \pm 13.2$ & $72.1 \pm 13.9$ & \\
\hline
\end{tabular}

Table 5: Differences in Parameters of Patients Receiving Oral AAs

found lower than such levels observed in those receiving hemodialysis, and this indicates a response of protein turnover to depletion or reduced release from tissue due to hyperinsulinemia [36]. In their study, Castellino et al. [37] found that peritoneal dialysis patients had lower basal rates of protein degradation, leucine oxidation and whole body protein synthesis than the controls. All of these findings indicate that the human body is predisposed by peritoneal dialysis to decreased anabolism, which is detrimental if nutrient intake is reduced or during superimposed catabolic illnesses [20,38,39]. Another study found that peritoneal dialysis with dialysates that contained dextrose alone elevated insulin levels by up to 3 times as much, while decreasing amino acid levels by $20-25 \%$ [40]. Such previous work demonstrates that moderate hyperinsulinemia in the fasting state while patients receive PD treatment with dextrose alone leads to significant antiproteolytic activity, but a parallel decrease in amino acid availability for protein synthesis conceals this activity [41].

A single dose of peritoneal dialysis solution with $1.5 \%$ to $4.25 \%$ glucose may provide an approximate calorie load of 50 to 300 $\mathrm{kcal}$, which accounts for $30 \%$ of the total daily energy need of PD patients [42]. To date, the $1.1 \%$ amino acid-based peritoneal dialysis solution (Table 6) (by Nutrineal', Baxter) is considered the ideal wellbalanced PD solution, since it contains all essential amino acids and six nonessential amino acids and electrolytes (such as lactate at 40 $\mathrm{mmol} / \mathrm{L}$ ) [43]. If dextrose and amino acids are used in combination, the suppression of muscle protein degradation and stimulation of muscle protein synthesis give rise to a cumulative effect. Providing a steady supply of amino acids with calories may lead to utilization of amino acids for protein synthesis instead of oxidation of amino acids, which limits acid and urea production. Some studies have suggested that dialysates combining dextrose and amino acids are a better choice to maintain muscle mass in patients with lower nutritional intake levels [44]. On the other hand, mixtures of AA plus glucose as a source of proteins have been shown to have almost the same effect with glucose only solutions in controlling protein loss [6].

In an ordinary CAPD procedure with a dwell time of 6 hours, if performed with intraperitoneal $1.1 \%$ AA solution, the amino acid reabsorption amount nears 16 grams [45], though the effects of supplementation of intraperitoneal AAs on nutrition still remains obscure. A prospective cohort study with a relatively large sample size of 183 patients receiving PD found no significant improvement in body weight after treatment (2-19 months) with $1 \%$ AA dialysate replaced with one 2-L glucose-based exchange [9]. Consistent with these findings, no significant weight gain was observed in our study.

However, the use of amino-acid-based intraperitoneal solutions may be limited by adverse metabolic effects, such as metabolic acidosis, reduced ultrafiltration, uremia, and poor oral intake [46]. In 


\begin{tabular}{|c|c|}
\hline Nutrinea ${ }^{\circledR}$ Composition & mg/dl \\
\hline L-Valine & 139 \\
\hline L-Leucine & 102 \\
\hline L-Isoleucine & 85 \\
\hline L-methionine & 85 \\
\hline L-lysine & 96 \\
\hline L-histidine & 71 \\
\hline L-threonine & 65 \\
\hline L-phenylalanine & 57 \\
\hline L-tryptophan & 27 \\
\hline L-arginine & 107 \\
\hline L-alanine & 95 \\
\hline L-proline & 60 \\
\hline Glycine & 51 \\
\hline L-serine & 51 \\
\hline L-tyrosine & 30 \\
\hline Sodium & 132 \\
\hline Calcium & 5 \\
\hline Magnesium & 0,61 \\
\hline Lactate & $360(40 \mathrm{mmol} / \mathrm{L})$ \\
\hline
\end{tabular}

Table 6: Composition of the $1.1 \%$ Amino Acids PD fluid

an interventional study, where PD patients with insufficient dietary protein intake $(1.0 \mathrm{~g}$ protein $/ \mathrm{kg} /$ day or less $)$ were treated with 1 or 2 bags of $2 \mathrm{~L} 1.1 \%$ AA solution exchanges, by Kopple et al found that serum urea levels of patients increased by about $30 \%$, and patients developed mild metabolic acidosis, mainly those treated with 2 bags of AA solutions a day [47]. In our study, no metabolic acidosis was observed after treatment with IP solution with AAs, probably because we administered 1 bag of solution daily instead of 2 bags, which was reported to cause acidosis. Besides, the increase in BUN levels was statistically significant.

Furthermore, evidence from another study indicates that although essential amino acids stimulate protein synthesis, if combined with sufficient oral intake of calories, they can inhibit whole-body protein degradation, which further supports the positive impact of the AAs on protein balance [48]. Tjiong et al. found that fractional albumin synthesis on AAs combined with glucose dialysis produced similar outcome with that on glucose only in two different states (fed and fasting). Protein intake alone failed to produce a significant increase in the fractional synthetic rate of albumin. On the other hand, oral protein intake managed to stimulate whole-body protein synthesis on a significant level [49]. In agreement with these findings, our results further support the idea of using IP AA-based solutions as a provision of nutritional supplement only, while considering normal oral intake of calories and proteins as the fundamental component of the treatment.

Another important finding by previous research was that dialysis solution with AAs induced an extra stimulus to protein synthesis, even in the fed state [50]. In their study, Kanbay et al. found that serum lipid parameters of solutions with AAs and other solutions administered during peritoneal dialysis did not differ significantly [51]. Contrary to expectations, the current study detected significant decrease in HDL levels of the Nutrineal group, with cholesterol values remaining stable.

Conducted by Li et al. with CAPD patients treated with amino acid-based PD fluid, a 3-year prospective randomized controlled study found that the albumin and cholesterol levels of the group receiving AA solution remained stable or elevated, while their normalized protein equivalent of nitrogen appearance and dietary protein intake levels increased [52]. The current study was unable to demonstrate the end nPCR values of patients, since we could not repeat the PET test at the end of the study.

In the IP AAs group, those with post-study albumin levels above $3 \mathrm{mg} / \mathrm{dl}$ had significantly lower CRP levels than did the patients in the low albumin strata $(<3.5 \mathrm{mg} / \mathrm{dl})$, which suggests that inflammation itself may be leading to malnutrition, as it also contributes to decreased albumin levels. The present study seems to be consistent with other research by Opatrna et al [32], which found that treatment with IP AAs solution resulted in declined phosphorus levels - a possible contributor in uremic toxicity.

Although all of these findings may seem promising, more research on this topic needs to be undertaken to conclusively determine the nutritional benefits of $1.1 \%$ amino acid-based solutions [43]. In spite of this, protein supplement appears to be a simple therapy that can be safely employed in protein energy wasting cases receiving CAPD, where it is tolerated [9]. Jiang et al reported that low protein diet combined with keto/amino acids significantly improved the pattern of plasma AAs in most patients receiving peritoneal dialysis [53]. In addition, a study by Boudville et al demonstrated that oral supplements, when taken before eating food, could improve caloric and protein intakes of PD patients significantly [54]. In their study investigating the effects of oral protein supplements in PD patients, Moretti et al found that protein supplement group had significantly improved levels of nPCR and albumin, but these levels declined after the patients discontinued the supplements [6].

Despite the positive results achieved with oral AAs, there have been several studies reporting no significant effect. For instance, Eustace et al reported that essential amino acids (EAAs) failed to produce a significant improvement in the serum albumin concentration in PD patients [55]. In our study, we observed that the group treated with oral AA preparations had lower post-study albumin and HbA1c levels than those recorded at baseline. It should be also noted that, due to challenges associated with oral administration or gastrointestinal side effects, oral amino acid supplements (tablets) may not be taken in effective doses. In the group receiving oral AAs supplements, the Kt/V and nPCR levels declined independent of albumin levels. In this group, 18 out of 20 patients had a nPCR value greater than $0.8 \mathrm{~g} / \mathrm{kg} / \mathrm{d}$. In other words, declining albumin levels in a group assumed to have relatively better protein intake suggest that the amount of amino acids found in the oral keto/amino acid preparations fails to compensate for the loss of amino acids in these patients.

However, certain limitations of this study may have affected the accuracy of the results found. First of all, the amounts of protein intake through PD solutions and concentrations may not be homogeneous. Secondly, the malnutrition status of the participants was not thoroughly investigated with questionnaires and anthropometric measurements. Thirdly, other factors possibly affecting hypoalbuminemia, such as inadequate intake and haemodilution secondary to UF deficiency were not taken into consideration during the study. In addition, the amounts of amino acids received by both groups were not equal in weight (milligrams) -while the IP solution group received approximately 22 grams of AAs per day, the oral supplement group was able to receive roughly 9 grams per day. Also, the rate of AA absorption in the study groups could not be investigated. In order to maintain patient adherence to treatment, the number of daily doses of oral AAs supplements was not further increased to equalize the amounts received by both groups. In this respect, there was difference between the two groups, which meant a drawback for the group receiving oral AAs preparations. 


\section{Conclusion}

Intraperitoneal AA solution appears to have a better contribution in the treatment of hypoalbuminemia, as compared with oral AA supplements. Even though treatment with amino acid supplements administered either intraperitoneally or orally, can be considered a good nutritional support, it should be borne in mind that the important point is to increase the amount of dietary protein intake in individual patients.

\section{References}

1. Fouque D, Kalantar-Zadeh K, Kopple J, Cano N, Chauveau P, et al. (2008) A proposed nomenclature and diagnostic criteria for protein-energy wasting in acute and chronic kidney disease. Kidney Int 73: 391-398.

2. Mitch WE (2002) Insights into the abnormalities of chronic renal disease attributed to malnutrition. J Am Soc Nephrol 13 Suppl 1: S22-27.

3. Mitch WE (2002) Malnutrition: a frequent misdiagnosis for hemodialysis patients. J Clin Invest 110: 437-439

4. Kopple JD (1997) McCollum Award Lecture, 1996: protein-energy malnutrition in maintenance dialysis patients. Am J Clin Nutr 65: 1544-1557.

5. Olszowska A, Waniewski J, Werynski A, Anderstam B, Lindholm B, et al (2007) Peritoneal transport in peritoneal dialysis patients using glucose-based and amino acid-based solutions. Perit Dial Int 27: 544-553.

6. Tjiong HL, Zijlstra FJ, Rietveld T, Wattimena JL, Huijmans JG, et al. (2007) Peritoneal protein losses and cytokine generation in automated peritoneal dialysis with combined amino acids and glucose solutions. Mediators Inflamm 2007: 97272

7. Kaysen GA, Stevenson FT, Depner TA (1997) Determinants of albumin concentration in hemodialysis patients. Am J Kidney Dis 29: 658-668.

8. Kaysen GA, Dubin JA, Muller HG, Rosales LM, Levin NW (2000) The acute-phase response varies with time and predicts serum albumin levels in hemodialysis patients. The HEMO Study Group. Kidney Int 58: 346-352.

9. Tennankore KK, Bargman JM (2013) Nutrition and the kidney: recommendations for peritoneal dialysis. Adv Chronic Kidney Dis 20: 190-201.

10. Clinical practice guidelines for nutrition in chronic renal failure. K/DOQI National Kidney Foundation. (2000) Am J Kidney Dis 35: S1-140.

11. Chung SH, Carrero JJ, Lindholm B (2011) Causes of poor appetite in patients on peritoneal dialysis. J Ren Nutr 21: 12-15.

12. Kopple JD, Blumenkrantz MJ, Jones MR, Moran JK, Coburn JW (1982) Plasma amino acid levels and amino acid losses during continuous ambulatory peritoneal dialysis. Am J Clin Nutr 36: 395-402.

13. Krediet RT, Zuyderhoudt FM, Boeschoten EW, Arisz L (1986) Peritonea permeability to proteins in diabetic and non-diabetic continuous ambulatory peritoneal dialysis patients. Nephron 42: 133-140.

14. Westra WM, Kopple JD, Krediet RT, Appell M, Mehrotra R (2007) Dietary protein requirements and dialysate protein losses in chronic peritoneal dialysis patients. Perit Dial Int 27: 192-195.

15. Molfino A, Laviano A, Rossi Fanelli F, Muscaritoli M, Chiappini MG (2007) Is des-acyl ghrelin contributing to uremic anorexia? Am J Clin Nutr 86: 1550-1551.

16. Carrero JJ, Heimburger O, Stenvinkel P (2007) Reply to A Molfino et al. Am J Clin Nutr 86: 1551-3

17. Mitch WE, May RC, Maroni BJ, Druml W (1989) Protein and amino acid metabolism in uremia: influence of metabolic acidosis. Kidney Int Suppl 27 S205-207.

18. Mehrotra R, Kopple JD, Wolfson M (2003) Metabolic acidosis in maintenance dialysis patients: clinical considerations. Kidney Int Supple: S13-25.

19. Prinsen BH, Rabelink TJ, Beutler JJ, Kaysen GA, De Boer J, et al. (2003) Increased albumin and fibrinogen synthesis rate in patients with chronic renal failure. Kidney Int 64: 1495-1504.

20. Garibotto G, Sofia A, Saffioti S, Bonanni A, Mannucci I, et al. (2013) Effects of peritoneal dialysis on protein metabolism. Nutr Metab Cardiovasc Dis 23 Supp 1: S25-30.
21. Kirsch R, Frith L, Black E, Hoffenberg R (1968) Regulation of albumin synthesis and catabolism by alteration of dietary protein. Nature 217: 578-579.

22. James WP, Hay AM (1968) Albumin metabolism: effect of the nutritional state and the dietary protein intake. J Clin Invest 47: 1958-1972.

23. Kaysen GA, Dubin JA, Muller HG, Mitch WE, Rosales LM, et al. (2002) Relationships among inflammation, nutrition and physiological mechanisms establishing albumin levels in hemodialysis patients. Kidney Int 61: 2240-2249.

24. Herzig KA, Purdie DM, Chang W, Brown AM, Hawley CM, et al. (2001) Is C-reactive protein a useful predictor of outcome in peritoneal dialysis patients? J Am Soc Nephrol 12: 814-821.

25. Kelman L, Saunders SJ, Frith L, Wicht S, Corrigal A (1972) Effects of dietary protein restriction on albumin synthesis, albumin catabolism, and the plasma aminogram. Am J Clin Nutr 25: 1174-1178.

26. Heimbürger O, Qureshi AR, Blaner WS, Berglund L, Stenvinkel P (2000) Handgrip muscle strength, lean body mass, and plasma proteins as markers of nutritional status in patients with chronic renal failure close to start of dialysis therapy. Am J Kidney Dis 36: 1213-1225.

27. Stenvinkel P, Barany P, Chung SH, Lindholm B, Heimbürger O (2002) A comparative analysis of nutritional parameters as predictors of outcome in male and female ESRD patients. Nephrol Dial Transplant 17: 1266-1274.

28. de Mutsert R, Grootendorst DC, Indemans F, Boeschoten EW, Krediet RT, et al. (2009) Association between serum albumin and mortality in dialysis patients is partly explained by inflammation, and not by malnutrition. J Ren Nutr 19 : 127-135.

29. Friedman AN, Fadem SZ (2010) Reassessment of albumin as a nutritional marker in kidney disease. J Am Soc Nephrol 21: 223-230.

30. Churchill DN, Taylor DW, Keshaviah PR (1996) Adequacy of dialysis and nutrition in continuous peritoneal dialysis: association with clinical outcomes. Canada-USA (CANUSA) Peritoneal Dialysis Study Group. J Am Soc Nephro 7: 198-207.

31. Harty J, Boulton H, Faragher B, Venning M, Gokal R (1996) The influence of small solute clearance on dietary protein intake in continuous ambulatory peritoneal dialysis patients: a methodologic analysis based on crosssectional and prospective studies. Am J Kidney Dis 28: 553-560.

32. Opatrná S, Liska J, Vít L, Hostasová A Opatrný K Jr. (1997) The effect of dialysis solutions containing amino acids on the nutritional status of patients treated with continuous ambulatory peritoneal dialysis. Cas Lek Cesk 136: 409-412

33. Moretti HD, Johnson AM, Keeling-Hathaway TJ (2009) Effects of protein supplementation in chronic hemodialysis and peritoneal dialysis patients. J Ren Nutr 19: 298-303.

34. Kang DH, Yoon KI, Choi KB, Lee R, Lee HY, et al. (1999) Relationship of peritoneal membrane transport characteristics to the nutritional status in CAPD patients. Nephrol Dial Transplant 14: 1715-1722.

35. Churchill DN, Thorpe KE, Nolph KD, Keshaviah PR, Oreopoulos DG, et al. (1998) Increased peritoneal membrane transport is associated with decreased patient and technique survival for continuous peritoneal dialysis patients. J Am Soc Nephrol 9: 1285-1292.

36. Garibotto G, Pastorino N, Dertenois L. Protein and amino acid metabolism in renal disease and in renal failure. In: Kopple JD, Massry S, editors. Nutritional management of renal diseases. Baltimore: William \& Wilkins; 2003.

37. Castellino P, Luzi L, Giordano M, Defronzo RA (1999) Effects of insulin and amino acids on glucose and leucine metabolism in CAPD patients. J Am Soc Nephrol 10: 1050-1058.

38. Garibotto G, Sofia A, Canepa A, Saffioti S, Sacco P, et al (2001) Acute effects of peritoneal dialysis with dialysates containing dextrose or dextrose and amino acids on muscle protein turnover in patients with chronic renal failure. J Am Soc Nephrol 12: 557-567.

39. Sofia A, Russo R, Saffioti S, Sacco P, Dertenois L, et al. (2002) [Acute effects of peritoneal dialysis on muscle protein turnover]. G Ital Nefrol 19: 37-43.

40. Löfberg E, Wernerman J, Norée LO, von der Decken A, Vinnars E (1991) Ribosome and free amino acid content in muscle during hemodialysis. Kidney Int 39: 984-989.

41. Garibotto G, Sofia A, Saffioti S, Bonanni A, Mannucci I, et al. (2010) Amino acid and protein metabolism in the human kidney and in patients with chronic kidney disease. Clinical Nutrition 29: 424-433 
Citation: Sarikaya M, Bora F, Inci A, Sari F, Gul S, et al (2015) Comparison of Intraperitoneal Amino Acid and Oral Amino Acid Supplements in Peritoneal Dialysis Patients. J Nephrol Ther 5: 192. doi:10.4172/2161-0959.1000192

Page 7 of 7

42. Grodstein GP, Blumenkrantz MJ, Kopple JD, Moran JK, Coburn JW (1981) Glucose absorption during continuous ambulatory peritoneal dialysis. Kidney Int 19: 564-567.

43. Mehrotra R (2013) Nutritional Issues in Peritoneal Dialysis Patients: How Do They Differ From That of Patients Undergoing Hemodialysis? J Ren Nutr 23 237-240.

44. Tjiong HL, Swart R, van den Berg JW, Fieren MW (2009) Amino Acid-based peritoneal dialysis solutions for malnutrition: new perspectives. Perit Dial Int 29: 384-393.

45. Han SH, Han DS (2012) Nutrition in patients on peritoneal dialysis. Nat Rev Nephrol 8: 163-175.

46. Jones M, Hagen T, Boyle CA, Vonesh E, Hamburger R, et al. (1998) Treatment of malnutrition with $1.1 \%$ amino acid peritoneal dialysis solution: results of a multicenter outpatient study. Am J Kidney Dis 32: 761-769.

47. Kopple JD, Bernard D, Messana J, Swartz R, Bergström J, et al. (1995) Treatment of malnourished CAPD patients with an amino acid based dialysate. Kidney Int 47: 1148-1157.

48. Delarue J, Maingourd C, Objois M, Pinault M, Cohen R, et al. (1999) Effects of an amino acid dialysate on leucine metabolism in continuous ambulatory peritoneal dialysis patients. Kidney Int 56: 1934-1943.
49. Tjiong HL, Fieren MW, Rietveld T, Wattimena JL, Schierbeek H, et al. (2007) Albumin and whole-body protein synthesis respond differently to intraperitoneal and oral amino acids. Kidney Int 72: 364-369.

50. Tjiong HL, Rietveld T, Wattimena JL, van den Berg JW, Kahriman D, et al (2007) Peritoneal dialysis with solutions containing amino acids plus glucose promotes protein synthesis during oral feeding. Clin J Am Soc Nephrol 2: 74-80.

51. Kanbay M, Bavbek N, Delibasi T, Koca C, Kaya A, et al. (2007) Effect of peritoneal dialysis solution type on serum lipid levels in end-stage renal disease. Ren Fail 29: 309-313.

52. Li FK, Chan LY, Woo JC, Ho SK, Lo WK, et al. (2003) A 3-year, prospective, randomized, controlled study on amino acid dialysate in patients on CAPD. Am J Kidney Dis 42: 173-183.

53. Jiang N, Qian J, Lin A, Fang W, Cao L, et al. (2010) Improved plasma amino acids pattern following 12 months of supplemented low-protein diet in peritoneal dialysis patients. Ren Fail 32: 709-715.

54. Boudville N, Rangan A, Moody H (2003) Oral nutritional supplementation increases caloric and protein intake in peritoneal dialysis patients. Am J Kidney Dis 41: 658-663.

55. Eustace JA Coresh J, Kutchey C, Te PL, Gimenez LF, et al. (2000) Randomized double-blind trial of oral essential amino acids for dialysisassociated hypoalbuminemia. Kidney Int. 2000 Jun;57(6):2527-2538. 